\title{
Palindromic Rheumatism-Like Migratory Non-Erosive Seronegative Polyarthritis in a Patient With Metastatic Conjunctival Malignant Melanoma
}

\author{
Pınar DORUK ANALAN \\ Department of Physical Medicine and Rehabilitation, Medical Faculty of Başkent University, Ankara, Turkey
}

Malignant melanoma of the conjunctiva is an extremely rare extraocular neoplasm. Local recurrence and metastases of this malignancy have been well documented in the literature, ${ }^{1,2}$ but there does not seem to be any information regarding cases of paraneoplastic polyarthritis arising from this metastatic malignancy. Herein, we describe the case of a patient with palindromic rheumatism (PR)-like migratory non-erosive seronegative polyarthritis in conjunction with metastatic conjunctival malignant melanoma.

A 51-year-old female patient was admitted to our clinic with a three-year history of transient and recurrent pain and swelling in her left upper extremity. She had been diagnosed with left conjunctival malignant melanoma with multiple metastases. She started to feel pain and swelling in her left shoulder that radiated to all of the joints in her left upper extremity in the form of migratory and transient recurrent attacks. At times, these symptoms would subside completely without any residual disability, but they would then begin again in other joints of the same extremity. The symptoms always developed quickly and reached their peak within a few days. She had variable symptom-free intervals between the attacks which coincided with her history of pain and swelling.

Her physical examination revealed active arthritis in her upper extremity joints. Laboratory tests found an erythrocyte sedimentation rate of $84 \mathrm{~mm} / \mathrm{h}$ and a C-reactive protein level of $38.8 \mathrm{mg} / \mathrm{L}$, but her rheumatoid factor serum and anti-cyclic citrullinated peptide antibody levels were within normal limits. The plain radiographs were normal.

She was prescribed non-steroidal antiinflammatory drugs, prednisone $5 \mathrm{mg} / \mathrm{per}$ day, oral methotrexate $7.5 \mathrm{mg} / \mathrm{per}$ week, and folinic acid $5 \mathrm{mg} / \mathrm{per}$ week. At the first follow-up appointment, patient's attacks had resolved completely with these medications.

Palindromic rheumatism is an uncommon condition characterized by irregular, recurrent episodes of mostly oligoarticular arthritis with peri- and para-articular tissue inflammation that can last from a few hours to several days with variable symptom-free intervals. It leaves no residual clinical and radiographic changes, and between attacks, the joints are completely normal and asymptomatic. Because no distinct clinical, laboratory, or radiological markers have been identified, a diagnosis of PR is currently based on clinical features and the exclusion of other forms of episodic arthritis. ${ }^{3-8}$ Laboratory tests should also show an elevated erythrocyte sedimentation rate and a higher number of acute phase reactants during the attacks, with these remaining at normal levels between the attacks. ${ }^{4,6,9}$ Our patient

Received: June 09, 2015 Accepted: November 05, 2015 Published online: November 30, 2015

Correspondence: Pınar Doruk Analan, MD. Başkent Üniversitesi Adana Uygulama ve Araştırma Merkezi Fizik Tedavi ve Rehabilitasyon Anabilim Dalı, 01250 Yüreğir, Adana, Turkey. Tel: +90 322 - 3444444 e-mail: doruk.pinar@gmail.com

(02016 Turkish League Against Rheumatism. All rights reserved. 
was consistent with the features mentioned above. Therefore, she was diagnosed with PR-like migratory non-erosive polyarthritis. Moreover, anti-cyclic citrullinated peptide antibodies are found in a high proportion of patients with $\mathrm{PR},{ }^{8}$ but our patient tested negative for these. Nevertheless, a negative result cannot eliminate the possibility of PR. Many wide-ranging treatment modalities exist for PR, but to date, no consensus exists regarding which is the best. ${ }^{8,10}$ We prescribed non-steroidal anti-inflammatory drugs, prednisone, and methotrexate to our patient, and during the follow-up period, she reported that she experienced a remission of her arthritic attacks as a by-product of using these drugs.

\section{Declaration of conflicting interests}

The author declared no conflicts of interest with respect to the authorship and/or publication of this article.

\section{Funding}

The author received no financial support for the research and/or authorship of this article.

\section{REFERENCES}

1. Manidakis N, Polyzois I, Tsialogiannis E, Marples M, Boon A, Tsiridis E. Metastatic malignant melanoma of the conjunctiva: a case report. Cases J 2009;2:125.

2. Choi J, Kim M, Park HS, Lee SY. Clinical followup of conjunctival malignant melanoma. Korean $\mathrm{J}$
Ophthalmol 2005;19:91-5.

3. Chen HH, Lan JL, Hung GD, Chen YM, Lan HH, Chen DY. Association of ultrasonographic findings of synovitis with anti-cyclic citrullinated Peptide antibodies and rheumatoid factor in patients with palindromic rheumatism during active episodes. J Ultrasound Med 2009;28:1193-9.

4. Khabbazi A, Hajialiloo M, Kolahi S, Soroosh M, Esalatmanesh K, Sharif S. A multicenter study of clinical and laboratory findings of palindromic rheumatism in Iran. Int J Rheum Dis 2012;15:427-30.

5. King BG Jr, Evans EB. Palindromic rheumatism: an unusual cause of the inflammatory joint. Two case reports and a review. J Bone Joint Surg Am 1974;56:142-4.

6. Kaushik P. Palindromic rheumatism: a descriptive report of seven cases from North Dakota and a short review of literature. Clin Rheumatol 2010;29:83-6.

7. Guerne PA, Weisman MH. Palindromic rheumatism: part of or apart from the spectrum of rheumatoid arthritis. Am J Med 1992;93:451-60.

8. Salvador G, Gomez A, Vinas O, Ercilla G, Canete $\mathrm{JD}$, Munoz-Gomez J, et al. Prevalence and clinical significance of anti-cyclic citrullinated peptide and antikeratin antibodies in palindromic rheumatism. An abortive form of rheumatoid arthritis? Rheumatology (Oxford) 2003;42:972-5.

9. Gonzalez-Lopez L, Gamez-Nava JI, Jhangri GS, Ramos-Remus C, Russell AS, Suarez-Almazor ME. Prognostic factors for the development of rheumatoid arthritis and other connective tissue diseases in patients with palindromic rheumatism. $\mathrm{J}$ Rheumatol 1999;26:540-5.

10. Harris ED. Clinical features of rheumatoid arthritis. In: Ruddy S, Harris E, Sledge C, editors. Kelly's Textbook of Rheumatology. 6th ed. Philadelphia: WB Saunders Company; 2001. p. 967-1000. 